\title{
INFLUENCE OF ALL OR PARTIAL REPLACEMENT OF MORINGA FROM BERSEEM ON THE PRODUCTIVE PERFORMANCE OF SHEEP
}

\author{
Amany A. Khayyal; A.M. Shwerab; M.S. Khalel; A.A. Hassan and M.H. Yacout \\ Department of By-Products Utilization, Animal Production Research Institute, Agricultural Research \\ Center, Dokki, Giza, Egypt.
}

(Received 4/2/2015, Accepted 22/3/2015)

\section{SUMMARY}

$\mathrm{T}$ This study was conducted to investigate the effect of inclusion Moringa oleifera (MO) to be partially or all replace berseem in sheep ration and its effect on nutrients digestibility, in-sacco effective degradability of dry matter (DM) and crude protein (CP) of fresh berseem (Trifolium alexandrinum) against Moringa oleifera forage, dietary nitrogen utilization, rumen fermentation activity, productive performance and blood parameters of Barki sheep. Digestibility trials were conducted with Barki rams, while rumen fermentation trials were conducted with fistulated Barki ewes. Feeding trials were applied with thirty male growing lambs. Thirty male Barki sheep $(25.37 \pm 0.37 \mathrm{~kg}$, and 7 months of age) were randomly divided into five similar groups (6 each) for a feeding period of 75 days, where weight was recorded and blood samples were collected at end of the feeding period. Experimental rations based on $60 \%$ $\mathrm{CFM}+40 \%$ fresh berseem $\left(\mathrm{R}_{1}\right) ; 60 \% \mathrm{CFM}+30 \%$ berseem $+10 \%$ moringa $\left(\mathrm{R}_{2}\right) ; 60 \% \mathrm{CFM}+20 \%$ berseem + $20 \%$ moringa $\left(\mathrm{R}_{3}\right) ; 60 \% \mathrm{CFM}+10 \%$ berseem $+30 \%$ moringa $\left(\mathrm{R}_{4}\right)$ and $60 \% \mathrm{CFM}+40 \%$ moringa $\left(\mathrm{R}_{5}\right)$. Results indicated that higher nutrients digestibility associated moringa containing rations, where the $\mathrm{R}_{4}$ containing $\left(10 \%\right.$ berseem $+30 \%$ moringa) and $\mathrm{R}_{5}(40 \%$ moringa $)$ had the highest $(\mathrm{P}<0.05)$ digestibility values for all nutrients followed by those of $\mathrm{R}_{3}(20 \%$ berseem $+20 \%$ moringa). While, the lowest values were recorded with $\mathrm{R}_{1}$ containing $40 \%$ berseem ( $0 \%$ moringa). Nutritive values expressed as TDN was $(\mathrm{P}<0.05)$ higher for $\mathrm{R}_{4}$ and $\mathrm{R}_{5}$ than $\mathrm{R}_{1}$, while $\mathrm{DCP}$ was $(\mathrm{P}<0.05)$ higher for all moringa rations $\left(\mathrm{R}_{2}, \mathrm{R}_{3}, \mathrm{R}_{4}\right.$ and $\left.\mathrm{R}_{5}\right)$ than $\mathrm{R}_{1}$. Results of nitrogen utilization as well showed remarkable $(\mathrm{P}<0.05)$ increase of $\mathrm{N}$-retained as \% of $\mathrm{N}-$ absorbed and relative to $\mathrm{N}$-intake or digestible $\mathrm{N}$ with moringa containing rations. The results indicated that feeding moringa forage in partial or complete substitution of berseem fodder improved nitrogen utilization with all moringa rations in comparison to $\mathrm{R}_{1}$. Rumen liquor $\mathrm{pH}$ values and $\mathrm{NH}_{3}-\mathrm{N}$ concentration were lower $(\mathrm{P}<0.05)$ with increasing moringa in rations $\left(\mathrm{R}_{3}, \mathrm{R}_{4}\right.$ and $\left.\mathrm{R}_{5}\right)$ than $\mathrm{R}_{1}$ and $\mathrm{R}_{2}$, while total VFA's concentration was remarkably higher for $\mathrm{R}_{3}, \mathrm{R}_{4}$ and $\mathrm{R}_{5}$ than $\mathrm{R}_{1}$ and $\mathrm{R}_{2}$ experimental rations. In similar trend, microbial nitrogen yield was greater with the moringa rations $\left(\mathrm{R}_{5}\right)$ than that of $\mathrm{R}_{1}(40 \%$ berseem containing ration). Molar proportion \% of propionic acid and butyric acid were insignificantly lower with increasing moringa in experimental rations. Acetic acid, acetic: propionic ratio and rumen volume $(\mathrm{L})$ were higher $(\mathrm{P}<0.05)$ with increasing moringa in rations. Effective degradability of DM and ruminal undegradable protein (RUP) were significantly increased with increasing the level of moringa up to $40 \%$. Economic return and economic efficiency were higher for moringa than berseem. Feeding moringa rations was associated with higher $(\mathrm{P}<0.05)$ blood glucose concentration, total protein, albumin and globulin with increase moringa in rations compared with the control ration. Moreover, blood cholesterol and urea was decreased $(\mathrm{P}<0.05)$ with moringa rations, however the effect was more pronounced with $40 \%$ moringa ration. Feeding moringa up to $40 \%$ of the whole daily ration did not badly affects liver or kidney functions. Under the conditions of this study, it's fair to conclude that; moringa oleifera is palatable and highly nutritious fodder. Therefore, the partial or complete replacement of berseem with moringa is highly recommended in the feeding practices of sheep.

Keyword: Moringa oleifera, sheep, digestibility, rumen fermentation, degradation kinetics, growth performance and blood parameters.

\section{INTRODUCTION}

Livestock plays a very important role as an integral part of farming and rural life in developing countries; providing food and the critical cash reserve and income for many farmers. The lack of sufficient feeds to meet the nutritional requirements of the existing animal population is one of the most critical problems of animal production in Egypt. Berseem (Trifolium alexandrinum) is the traditional Egyptian green fodder during winter season (from Nov. up end of May). About 1.400.000 feddan (feddan $=4200 \mathrm{~m}^{2}$ ) are annually cultivated with berseem for ruminants feeding. Abundant amounts of nearly 


\section{Khayyal et al.}

41,000,000 tons of berseem forage are available during winter (Agriculture Economics and Statistics, 2014), while, green fodders are scarcely available during summer season. Limited level of irrigated water and occupation of agricultural lands with traditional summer food crops (rice, corn. etc.) are the two main constrains make sufficient amount of green fodders unavailable in reasonable cost during summer season. So, there is a badly need to find type of perennial fodder plant capable to grow particularly in the sandy soil of the newly reclaimed lands. One of the most interesting trees is moringa (Moringa oleifera Lam.), (syns. Moringa pterygosperm, family Moringaceae) is a multipurpose tropical tree and small to medium evergreen or deciduous tree that can reach up to 10-12 m. It is mainly used for food and has numerous industrial, medicinal and agricultural uses, including animal feeding. This traditional plant was rediscovered in the 1990s and its cultivation has since become increasingly popular in Asia and Africa, where it is among the most economically valuable crops. It has been dubbed the "miracle tree" or "tree of life" in popular media (Bosch, 2004; Radovich, 2009; Orwa et al., 2009 and FAO, 2014). It is one of the most widely used species for fodder (Bakhashwain et al., 2010). It can grow in all types of soils and can tolerate dry seasons lasting up to 6 months (Mendieta-Araica et al., 2013). It is a multipurpose tree; leaves and green fresh pods are used as vegetables by humans and are rich in carotene and ascorbic acid with a good profile of amino acids (Makkar and Becker, 1996). It is also used as livestock feed and its twigs are reported to be very palatable to ruminants and have appreciable crude protein levels (Sutherland et al., 1990; Sarwatt et al., 2002 and Kimoro, 2002). Intensive production of moringa as green fodder can harvested 8 times at year gave about 300 tons per acre when harvested every 40 days grows and at high 50 to $60 \mathrm{~cm}$. The total dry matter (DM) yield from moringa is up to 24 tons $^{-1} \mathrm{y}^{-1}$ year $^{-1}$ (Reyes-Sánchez et al., 2006a). Furthermore, Moringa oleifera is a non-leguminous multipurpose tree with a high crude protein in the leaves $(251 \mathrm{~g} / \mathrm{kg} \mathrm{DM})$ and negligible content of tannis and other anti-nutritional compounds (Makkar and Becker, 1996 and Gidamis et al., 2003). Moringa plant contains significant amounts of vitamins $\mathrm{A}, \mathrm{B}$, and $\mathrm{C}$ in the foliage with a good profile of amino acids (Ferreira et al., 2008 and Mendieta-Araica et al., 2011). As fresh forage, moringa has been included in the diets of many different animals. Positive effects on the feeding behavior in goats (Manh et al., 2005) and on the growth rate in sheep (Ben Salem and Makkar, 2009); and had favorable production results with dairy cows (ReyesSánchez et al., 2006b). Moringa leaves and green pods are used as vegetables by humans and offer well an alternative source of protein to ruminants. Moreover, its twigs are very palatable to ruminants and have appreciable crude protein levels (Kaijage et al., 2003). Laboratory analysis (Asaolu, 2009) showed negligible amounts of tannins ( 1 to $23 \mathrm{~g} / \mathrm{kg}$ ) in all fractions of the Moringa oleifera plant and high levels of sulphur-containing amino acids. There has been an increasing interest in the use of moringa as a protein source for livestock (Asaolu et al., 2009 and 2010). During the last years, great attention has been given to moringa forage by many Egyptian animal nutritionists to overcome the difficulty of green fodder shortage particularly during summer season. So, this study was conducted to investigate the impact of feeding moringa fodder in partial or complete replacement of berseem forage in the feeding practices of Barki sheep.

\section{MATERIALS AND METHODS}

\section{Feeds and tested rations:}

The present study was carried out at Al- Noubaria Experimental Station affiliates Animal Production Research Institute, Agricultural Research Center, Giza, Egypt, in corporation with a private moringa farm located in Al-Noubaria province (about $180 \mathrm{~km}$ North Western Cairo City). Experimental fodders of $3^{\text {rd }}$ cut berseem (Trifolium alexandrinum) and moringa (Moringa oleifera Lam.) were daily collected and brought to the animal station at $6.00 \mathrm{a} . \mathrm{m}$. Five experimental rations based on changing the roughage type were fed on DM basis as: $\left.\mathrm{R}_{1}\right) 60 \%$ concentrate feed mixture $(\mathrm{CFM})+40 \%$ fresh berseem, $\left.\mathrm{R}_{2}\right) 60 \% \mathrm{CFM}$ $+30 \%$ fresh berseem $+10 \%$ fresh moringa, $\left.\mathrm{R}_{3}\right) 60 \% \mathrm{CFM}+20 \%$ fresh berseem $+20 \%$ fresh moringa, $\left.\mathrm{R}_{4}\right) 60 \% \mathrm{CFM}+10 \%$ fresh berseem $+30 \%$ fresh moringa and $\left.\mathrm{R}_{5}\right) 60 \% \mathrm{CFM}+40 \%$ fresh moringa. Calculated feeding value of the CFM was $65 \%$ total digestible nutrients (TDN) and $14 \%$ crude protein (CP). Proximate chemical analyses of CFM were determined according to the standard methods of A.O.A.C. (2007). Table (1) illustrated the chemical composition of CFM (on DM basis).

\section{Digestibility and nitrogen balance trials:}

Five digestibility and nitrogen balance trials were carried out using three Barki rams $(47.5 \pm 2 \mathrm{~kg}$, in average) for each ration consequently. Each trial lasted for four weeks; the first three weeks were as a preliminary period, followed by one week for feces and urine collection. Sheep were fed twice daily at 8.00 a.m. and 4.00 p.m. water was offered freely. Each animal was offered the tested diets according to 
NRC (1994). Chemical composition of feeds, feces and urine were determined according to A.O.A.C. (2007) methods. Sub samples $(20 \%)$ of feces and urine were taken once daily then stored at $-18{ }^{\circ} \mathrm{C}$ until analyses. Fecal samples were dried at $60{ }^{\circ} \mathrm{C}$ for $72 \mathrm{hrs}$. Feed and fecal samples were ground through 1 $\mathrm{mm}$ screen on a Wiley mill grinder and a sample of $50 \mathrm{gm} /$ (diet/sheep) was taken for analysis. The samples of feed and feces were analyzed for crude protein $(\mathrm{CP})$, crude fiber $(\mathrm{CF})$, ether extract (EE) and ash, while the urine samples were analyzed for nitrogen $(\mathrm{N})$ content according to A.O.A.C. (2007). Cell wall constituents (NDF, ADF and ADL) were determined according to Van Soest et al. (1991). Hemicellulose and cellulose were calculated by differences. Total phenolic components (TPC) were assayed by Folin-Ciocalteu-reagent $2 \mathrm{~N}$ (Sigma ${ }^{\circledR}$-Aldrich, El-Safua Co., Alexandria, Egypt) based on known concentrations of tannic acid as the calibration curve (Sigma®-Aldrich) according to Makkar and Becker (1993). Condensed tannins (CT) were determined according to Makkar (2003). Saponins were extracted and isolated according to Ahmad et al. (1990). Mineral extracts of berseem and moringa were prepared and analyzed for $\mathrm{Ca}$ and $\mathrm{Na}$ after a wet digestion with a mixture of nitric, sulphuric and perchloric acids using an atomic absorption spectrophotometer (Unicam 919). Phosphorus was determined colorimetrically, using molydbovanadate reagent according to A.O.A.C. (2007).

Table (1): Chemical composition of the concentrate feed mixture (on DM basis).

\begin{tabular}{lccccccc}
\hline Item & DM & OM & CP & CF & EE & NFE & Ash \\
\hline CFM & 89.81 & 93.27 & 13.64 & 6.96 & 2.53 & 70.14 & 6.73
\end{tabular}

The concentrate feed mixture (CFM) in cubes was formulated of: $35 \%$ ground yellow corn, $18 \%$ soybean meal, $28 \%$ wheat bran, $10 \%$ barley grain, $5 \%$ cane molasses, $2 \%$ limestone, $1 \%$ sodium chloride and $1 \%$ minerals \& vitamins mixture.

\section{Rumen fermentation:}

Rumen liquor samples were taken at $0,1,3$ and $6 \mathrm{hrs}$ after the morning meal from three fistulated female Barki ewes (weighed $43.00 \pm 1.5 \mathrm{Kg} \mathrm{BW}$ ) for each diet consequently. Collected rumen liquor was directly tested for $\mathrm{pH}$ using Orian 680 digital $\mathrm{pH}$ meter. Samples were strained through four layers of chesses cloth for each sampling time, while ammonia nitrogen $\left(\mathrm{NH}_{3}-\mathrm{N}\right)$ was determined by using magnesium oxide $(\mathrm{MgO})$ as described by the AL-Rabbat et al. (1971). Total volatile fatty acids (VFA's) concentration was estimated by using steam distillation methods (Warner, 1964); molar concentration of VFA's fraction was estimated by gas chromatography (Yang and Varga, 1989). Rumen volume was determined by colorimetric method of Cr-EDTA before, 3 and 6 hrs after feeding (El-Shazly et al., 1976). The microbial nitrogen synthesized $(\mathrm{gMN} / \mathrm{d})$ in the rumen of sheep fed the experimental diets was calculated using the model equation justified by Chen et al. (1991) as follow: $\mathrm{N}$ supply $(\mathrm{g} / \mathrm{day})=\ll \operatorname{Pax} 70 /$ $(0.83 \times 0.116 \times 1000) »$, where 70 is the $\mathrm{N}$ content $(\mathrm{mg} / \mathrm{mmol})$ of purines, $(\mathrm{Pa} \mathrm{mmol} /$ day $)$ is microbial purine absorbed by the animal. The supply of microbial $\mathrm{N}$ was calculated from $\mathrm{Pa}$ by assuming that: digestibility of microbial purines equals 0.83 and the purine- $\mathrm{N}$ : total microbial $\mathrm{N}$ ratio $=0.116$.

\section{Degradation kinetics:}

Nylon bags technique (Mehrez and Ørskov, 1977) was used to determine degradability of DM and CP for roughages. Two polyester bags $(7 \times 15 \mathrm{~cm}$ ) with pore size of $45 \mu \mathrm{m}$ were used for each incubation time. Approximately $6 \mathrm{~g}$ of air-dried roughages (ground to $2 \mathrm{~mm}$ ) were placed in each bag. All bags were incubated in the rumen of each sheep, then they were withdrawn after 3, 6, 12, 24, 48, 72 and 96h, rinsed in tap water until the water became clear, then they were squeezed gently. Microorganisms attached to the residual sample were eliminated by freezing at $-20^{\circ} \mathrm{C}$ (Kamel et al., 1995). Zero-time washing losses (a) were determined by washing 2 bags in running water for $15 \mathrm{~min}$. The degradation kinetics of DM and CP were estimated (in each bag) by fitting the disappearance values to the equation $P=a+b\left(1-e^{\text {-ct }}\right)$ as proposed by Ørskov and McDonald (1979), where P represents the disappearance after time " $t$ ". Leastsquares estimated of soluble fractions are defined as the rapidly degraded fraction (a), slowly degraded fraction (b) and the rate of degradation (c). The effective degradability (ED) for tested rations were estimated from the equation of McDonald (1981), where $E D=a+b c /(c+k), k$ is the out flow rate.

\section{Feeding trials:}

A feeding experiment was conducted for 75 days, using thirty male Barki sheep with an average live body weight $25.37 \pm 0.37 \mathrm{~kg}$, and 7 months of age were randomly divided into five similar groups (6 male each). Experimental rations based on $60 \% \mathrm{CFM}+40 \%$ fresh berseem $\left(\mathrm{R}_{1}\right) ; 60 \% \mathrm{CFM}+30 \%$ berseem + 


\section{Khayyal et al.}

$10 \%$ fresh moringa $\left(\mathrm{R}_{2}\right) ; 60 \% \mathrm{CFM}+20 \%$ berseem $+20 \%$ moringa $\left(\mathrm{R}_{3}\right) ; 60 \% \mathrm{CFM}+10 \%$ berseem + $30 \%$ moringa $\left(\mathrm{R}_{4}\right)$ and $60 \% \mathrm{CFM}+40 \%$ moringa $\left(\mathrm{R}_{5}\right)$. All rations were offered twice daily at 8.00 a.m. and 4.00 p.m. in two equal portions. Animals were housed in five shaded yards. Daily amounts of tested rations were calculated according to NRC (1994). Drinking water was available at all times.

\section{Blood biochemical constituents:}

Blood samples were collected at the end of the experimental period. Blood samples were withdrawn from the external jugular vein of each animal in heparinized tubes before feeding. Plasma was separated by centrifugation at $4000 \mathrm{rpm}$ for $15 \mathrm{~min}$; various chemical parameters were calorimetrically determined using commercial kits, following the same steps as described by the manufacturers. Glucose concentration was determined according to Trinder (1969). Total protein (TP) was determined according to Armstrong and Carr (1964); albumin was determined according to Doumas et al. (1971) and globulin was calculated by subtracting albumin from total protein. Cholesterol was determined according to Roeschlau et al. (1974); kidney function was evaluated by measuring blood urea using the colorimetric method of Henry and Todd (1974). Creatinine was measured according to Faulkner and King (1976). Liver function was assessed by measuring the activities of aspartate aminotrasferase (AST) and alanine aminotransferase (ALT) according to Reitman and Frankel (1957).

\section{Statistical analyses:}

Collected data were statistically analyzed using the method of least squares analysis of variance using General Linear Models (GLM) procedure (SAS, 2000). The model used was as follow: Yij $=\mu+\mathrm{Ti}+$ eij Where: $\mathrm{Yij}=$ an observation taken on the $\mathrm{jth}$ individual, $\mu=$ overall mean, $\mathrm{Ti}=$ a fixed effect of the ith treatment ( $\mathrm{i}=1$ to 5 ), eij = A random error assumed to be normally distributed with mean $=0$ and variance $=\sigma 2$. Significant differences among means were separated using LSD test according to Duncan (1955).

\section{RESULTS AND DISCUSSION}

\section{Chemical composition, cell wall constituents, minerals content and anti-nutritional factors of experimental forages:}

Data of chemical composition, cell wall constituents, and macro elements content of berseem (Trifolium alexandrinum) and Moringa oleifera green forages are shown in Table (2). Moisture content of moringa was lower than berseem (72.07 vs. 83.53\%). Dry matter composition showed that moringa forage contained higher crude protein (CP) equals one and half time have that of berseem (18.33 vs. $11.97 \%$ ), which is within the range of 15.6 to $26.4 \%$ reported by other workers (Malik et al., 1967; Gupta et al., 1989; Becker, 1995; Makkar and Becker, 1996 and 1997, Reyes Sánchez et al., 2006a; Ogbe and John, 2011 and Khalel et al., 2014). Crude fiber (CF) and nitrogen free extract (NFE) were lower in moringa than berseem. Both forages had high ash content being, $8.83 \%$ for berseem and $8.87 \%$ for moringa. Residual soil particles attached plants during harvesting might be the reason of high ash content. All cell wall constituents were slightly lower in moringa than berseem except hemicellulose. It is important to realize that the chemical composition of moringa can vary considerably mainly depending on the amount of smaller branches, twigs included along with the leaves in the leaf meal and may be due to the differences in the locality of its growth and the stage of maturity prior harvesting. This was shown by Fujihara et al. (2005) who analyzed different fractions of Moringa oleifera (leaves, seed cake, and soft twigs). The leaves and seed cake had a CP content of approximately 25 to $30 \%$ while leaves with soft twigs had a CP content of $19.5 \%$.

The CP content of soft twigs alone was yet somewhat lower but this fraction can be used for animals with lower nutrient requirements (Khalel et al., 2014). Macro elements content were remarkably higher in moringa than berseem except that for sodium which was two times higher in berseem than moringa. These results were to a great extent in agreement with those optioned by Moyo et al. (2011) in their comprehensive study on moringa dry leaves cultivated under South Africa eco-system. Calcium had the highest value of $(3.69 \%)$ but sodium had the lowest value $(0.21 \%)$. Total polyphenols, condensed tannins and saponins were higher in moringa than berseem forage. Polyphenols in this study $(2.53 \%)$ were lower than $4.3 \%$ previously reported by Foidl et al. (2001) for moringa leaves. It's worth noting, that at this present concentration simple phenols do not produce any adverse effects when consumed by animals. Meanwhile, these polyphenols have been reported to have multiple beneficial effects that include antioxidant activity, anti-inflammatory action, inhibition of platelets aggregation, antimicrobial and antitumor activities (Thurber and Fahey, 2009). Condensed tannins were $1.78 \%$ for moringa vs. $0.43 \%$ for 
berseem. Comparable value of condensed tannins being $1.4 \%$ was recorded by Foidl et al. (2001), for fresh moringa foliage while much higher value (3.12\%) was recorded for moringa dry leaves by Moyo et al. (2011). However, drying was reported to reduce condensed tannins by 15 to $30 \%$ relative to fresh plant (Vitti et al., 2005). Saponins were $1.72 \%$ for moringa vs. $0.83 \%$ for berseem. Comparable value of saponins being 1.60 and 1.75\% was recorded by Ogbe and John (2011) and Ojiako (2014), for Moringa oleifera leaves. Saponins are glycosides, which include steroid saponins and triterpenoid saponins (Dei et al., 2007). These compounds have been observed to kill protozoans, to impair the protein digestion and the uptake of vitamins and minerals in the gut and to act as hypoglycemic agent. Thus, these compounds affect animals in both positive and negative ways (Das et al., 2012).

Table (2): Chemical composition, cell wall constituents, minerals content and anti-nutritional factors of berseem and moringa forages.

\begin{tabular}{ccc}
\hline Item & Berseem clover & Moringa oleifera \\
\hline Chemical composition, \%: & & \\
Moisture & 83.53 & 72.07 \\
DM & 16.47 & 27.93 \\
OM & 91.17 & 91.13 \\
CP & 11.97 & 18.33 \\
CF & 26.15 & 21.46 \\
EE & 1.52 & 2.15 \\
NFE & 51.53 & 49.19 \\
Ash & 8.83 & 8.87 \\
NDF & & \\
ADF & 48.74 & 46.62 \\
ADL & 36.33 & 33.82 \\
Hemicellulose & 11.83 & 10.11 \\
Cellulose & 12.41 & 12.80 \\
Cell wall constituents, & 24.50 & 23.71 \\
Ca & & \\
P & 1.47 & 3.69 \\
Na & 0.24 & 0.33 \\
Macro elements, $\%$ & 0.49 & 0.21 \\
Total polyphenols & & \\
Condensed tannins & 1.28 & 2.53 \\
Anti-nutritional & 0.43 & 1.78 \\
& 0.83 & 1.72 \\
\hline
\end{tabular}

\section{Nutrients digestibility and dietary nitrogen utilization:}

Apparent nutrients digestion coefficients of experimental rations are given in Table (3). It's obviously that, $\mathrm{R}_{5}\left(40 \%\right.$ moringa) and $\mathrm{R}_{4}(10 \%$ berseem $+30 \%$ moringa $)$ had the highest $(\mathrm{P}<0.05)$ digestibility values for all nutrients followed by those of $R_{3}(20 \%$ berseem $+20 \%$ moringa), while the lowest values were recorded with $\mathrm{R}_{1}$ containing $40 \%$ berseem. The positive effect of moringa on nutrients digestibility could be regarded to its high content of slow degradable protein or essential amino acids needed to enhance rumen microbial activity. Similar assumption was reported by Poppi and McLennan (1995) that feeding moringa forage improved nitrogen supply and corrected $\mathrm{N}$ deficiency of low quality diets. Moreover, Reyes-Sánchez et al. (2006b) reported that feeding moringa forage had limited effect on rumen fill due to its low NDF content in which feed intake and nutrients digestibility could be improved. As a result of the higher nutrients digestibility associated moringa containing rations, nutritive values expressed as TDN was $(\mathrm{P}<0.05)$ higher for $\mathrm{R}_{5}$ and $\mathrm{R}_{4}$ than $\mathrm{R}_{1}$ being respectively, 66.79 and 64.91 vs. 59.78 for TDN\%, while DCP was $(\mathrm{P}<0.05)$ higher for all moringa rations $\left(\mathrm{R}_{2}, \mathrm{R}_{3}, \mathrm{R}_{4}\right.$ and $\left.\mathrm{R}_{5}\right)$ than $\mathrm{R}_{1}$ being respectively, 8.56, 9.06, 9.48 and 9.92 vs. 8.08 for DCP\%. The present results are in good agreement with those reported by Newton et al. (2010), Mendieta-Araica et al. (2013) and Nouman et al. (2013). They also reported that moringa forage is rich in most nutrients as its addition to low quality diets is useful to increase their dry matter intake and nutrients digestibility. Results of nitrogen utilization as well showed remarkable $(\mathrm{P}<0.05)$ increase of $\mathrm{N}$-absorbed and $\mathrm{N}$-retained relative to increase $\mathrm{N}$-intake for moringa containing rations. Values of $\mathrm{N}$-intake were 21.76, 22.82, 23.89, 24.94 and 26.01 and N-retained were 5.15, 5.58, 6.77, 7.64 and 8.03 for $R_{1}, R_{2}, R_{3}, R_{4}$ and $R_{5}$, respectively. The results indicated that 


\section{Khayyal et al.}

feeding moringa forage in partial or complete substitution of berseem fodder could improve dietary Nutilization with all moringa rations. These results confirmed the previous findings of Mendieta-Aracia et al. (2013) and Nouman et al. (2013) that moringa leaves had good quality protein, rich of essential amino acids which can enhance dietary $\mathrm{N}$ utilization and improve animal productivity.

Table (3): Dry matter intake (g/h/d), nutrients digestibility, nutritive value and nitrogen utilization of the experimental rations fed to male Barki sheep (means $\pm \mathrm{SE}$ ).

\begin{tabular}{|c|c|c|c|c|c|}
\hline \multirow{2}{*}{ Item } & \multicolumn{5}{|c|}{ Experimental rations } \\
\hline & $\mathrm{R}_{1}$ & $\mathrm{R}_{2}$ & $\mathrm{R}_{3}$ & $\mathrm{R}_{4}$ & $\mathrm{R}_{5}$ \\
\hline \multicolumn{6}{|c|}{ Dry matter intake $(\mathrm{g} / \mathrm{h} / \mathrm{d})$ : } \\
\hline Concentrate & 628.67 & 628.67 & 628.67 & 628.67 & 628.67 \\
\hline Berseem & 419.99 & 314.57 & 209.99 & 104.58 & - \\
\hline Moringa & - & 104.74 & 209.47 & 314.21 & 418.95 \\
\hline TFI* & 419.99 & 419.31 & 419.46 & 418.79 & 418.95 \\
\hline Total DMI & 1048.66 & 1047.98 & 1048.13 & 1047.46 & 1047.62 \\
\hline \multicolumn{6}{|c|}{ Digestibility coefficients $(\%)$ : } \\
\hline DM & $60.12 \pm 0.32^{\mathrm{d}}$ & $61.24 \pm 0.41^{\mathrm{cd}}$ & $64.95 \pm 0.45^{\mathrm{c}}$ & $66.01 \pm 0.17^{\mathrm{b}}$ & $67.20 \pm 0.26^{\mathrm{a}}$ \\
\hline $\mathrm{OM}$ & $62.92 \pm 0.42^{\mathrm{c}}$ & $63.29 \pm 0.38^{c}$ & $65.89 \pm 0.35^{\mathrm{b}}$ & $68.02 \pm 0.44^{\mathrm{ab}}$ & $69.95 \pm 0.31^{\mathrm{a}}$ \\
\hline $\mathrm{CP}$ & $62.28 \pm 0.47^{\mathrm{b}}$ & $62.94 \pm 0.36^{\mathrm{b}}$ & $63.58 \pm 0.24^{\mathrm{a}}$ & $63.71 \pm 0.13^{\mathrm{a}}$ & $63.91 \pm 0.12^{\mathrm{a}}$ \\
\hline $\mathrm{CF}$ & $55.82 \pm 0.17^{\mathrm{d}}$ & $55.83 \pm 0.14^{\mathrm{d}}$ & $57.82 \pm 0.08^{c}$ & $58.45 \pm 0.25^{\mathrm{b}}$ & $60.18 \pm 0.26^{\mathrm{a}}$ \\
\hline $\mathrm{EE}$ & $61.17 \pm 0.15^{\mathrm{d}}$ & $64.59 \pm 0.13^{c}$ & $63.73 \pm 0.27^{\mathrm{c}}$ & $70.64 \pm 0.14^{\mathrm{b}}$ & $72.28 \pm 0.29^{\mathrm{a}}$ \\
\hline NFE & $64.93 \pm 0.34^{\mathrm{d}}$ & $65.02 \pm 0.14^{\mathrm{d}}$ & $68.26 \pm 0.09^{c}$ & $71.01 \pm 0.23^{\mathrm{b}}$ & $73.40 \pm 0.18^{\mathrm{a}}$ \\
\hline \multicolumn{6}{|l|}{ Nutritive value (\%): } \\
\hline TDN & $59.78 \pm 0.58^{\mathrm{d}}$ & $60.27 \pm 0.49^{\mathrm{d}}$ & $62.69 \pm 0.13^{c}$ & $64.91 \pm 0.28^{\mathrm{b}}$ & $66.79 \pm 0.24^{\mathrm{a}}$ \\
\hline DCP & $8.08 \pm 0.16^{\mathrm{d}}$ & $8.56 \pm 0.11^{\mathrm{c}}$ & $9.06 \pm 0.19^{c}$ & $9.48 \pm 0.14^{\mathrm{b}}$ & $9.92 \pm 0.21^{\mathrm{a}}$ \\
\hline \multicolumn{6}{|c|}{ Nitrogen utilization $(\mathrm{g} / \mathrm{h} / \mathrm{d})$ : } \\
\hline $\mathrm{N}$-intake $(\mathrm{g} / \mathrm{d})$ & $21.76 \pm 0.25^{\mathrm{b}}$ & $22.82 \pm 0.22^{\mathrm{b}}$ & $23.89 \pm 0.28^{\mathrm{ab}}$ & $24.94 \pm 0.34^{\mathrm{a}}$ & $26.01 \pm 0.25^{\mathrm{a}}$ \\
\hline N-absorbed (g/d) & $13.55 \pm 0.25^{\mathrm{d}}$ & $14.36 \pm 0.22^{\mathrm{c}}$ & $15.19 \pm 0.19^{b}$ & $15.89 \pm 0.16^{b}$ & $16.62 \pm 0.21^{\mathrm{a}}$ \\
\hline N-retained $(\mathrm{g} / \mathrm{d})$ & $5.15 \pm 0.09^{\mathrm{e}}$ & $5.58 \pm 0.11^{\mathrm{d}}$ & $6.77 \pm 0.13^{c}$ & $7.64 \pm 0.15^{\mathrm{b}}$ & $8.03 \pm 0.20^{\mathrm{a}}$ \\
\hline $\begin{array}{l}\mathrm{N} \text { - retained e as \% of } \\
\mathrm{N} \text {-intake }\end{array}$ & $23.67 \pm 0.35^{\mathrm{d}}$ & $24.45 \pm 0.22^{\mathrm{c}}$ & $28.34 \pm 0.27^{b}$ & $30.63 \pm 0.21^{\mathrm{a}}$ & $30.87 \pm 0.47^{\mathrm{a}}$ \\
\hline $\begin{array}{l}\mathrm{N} \text { - retained as \% of } \\
\mathrm{N} \text {-absorbed }\end{array}$ & $38.01 \pm 0.55^{\mathrm{c}}$ & $38.86 \pm 0.76^{c}$ & $44.57 \pm 0.33^{b}$ & $48.08 \pm 0.39^{\mathrm{a}}$ & $48.32 \pm 0.41^{\mathrm{a}}$ \\
\hline
\end{tabular}

$a, b, c, d$ and $e:$ means in the same row with different superscripts are significantly $(P<0.05)$ different.

$* T F I=$ Total fodder intake [berseem (Trifolium alexandrinum) + Moringa oleifera] .

$R_{l}=60 \%$ CFM $+40 \%$ berseem (Trifolium alexandrinum).

$R_{2}=60 \%$ CFM $+30 \%$ berseem (Trifolium alexandrinum) $+10 \%$ Moringa oleifera .

$R_{3}=60 \% C F M+20 \%$ berseem (Trifolium alexandrinum) $+20 \%$ Moringa oleifera .

$R_{4}=60 \% C F M+10 \%$ berseem (Trifolium alexandrinum) $+30 \%$ Moringa oleifera.

$R_{5}=60 \% C F M+40 \%$ Moringa oleifera.

\section{Rumen fermentation:}

Rumen fermentation activity of animals fed experimental rations is given in Table (4). Rumen liquor $\mathrm{pH}$ values and $\mathrm{NH}_{3}-\mathrm{N}$ concentration were lower $(\mathrm{P}<0.05)$ with increasing moringa in rations $\left(\mathrm{R}_{3}, \mathrm{R}_{4}\right.$ and $R_{5}$ ) than $R_{1}$ and $R_{2}$, while total VFA's concentration was remarkably higher for $R_{3}, R_{4}$ and $R_{5}$ than $R_{1}$ and $R_{2}$. In similar trend, microbial nitrogen yield was greater with the moringa rations $\left(R_{5}\right)$ than that of $R_{1}$ (40\% berseem containing ration). Molar proportion \% of propionic acid and butyric acid were insignificantly lower with increasing moringa in experimental rations. Acetic acid, acetic: propionic ratio and rumen volume $(\mathrm{L})$ were higher $(\mathrm{P}<0.05)$ with increasing moringa in rations. These results are matching with the results of degradation kinetics (Table 5) that moringa had higher DM effective degradability but lower soluble and degradable CP than berseem forage. Moreover, the obvious high microbial protein synthesis and dietary nitrogen utilization may indicated that moringa containing rations improved the synchrony between dietary energy and protein which was resulted in lower ruminal ammonia-N and higher VFA's than berseem. The present results confirmed the previous results of Hoffmann et al. (2003) who stated that, the low ruminal $\mathrm{NH}_{3}-\mathrm{N}$ associated with moringa supplementation is attributed to its low protein degradability. Soliva et al. (2005) concluded that moringa leaves are not suggested as a source of rumen protected protein. They proposed that it promotes rumen microbial protein synthesis due to its substantial contents of readily fermentable $\mathrm{N}$ and energy. They concluded that it still 
has to be shown whether or not this protein is arriving at the duodenum of the ruminant and in how far these feeds are competitive to the more common protein sources in highly productive growing or milk producing ruminants. However, Alexander et al. (2008) found that $\mathrm{NH}_{3}-\mathrm{N}$ concentration was decreased when a medium of white clover hay was incubated with moringa leaves extract. Some other studies mentioned that, the relatively high contents of tannins and saponins which are naturely occurring in moringa leaves could affect ruminal proteolytic activity resulted in lower ruminal ammonia-N (Oliveira $e t$ al., 1999; Sliwinski et al., 2002 and Soliva et al., 2005). The later assumption may not hold true since VFA's concentration and microbial yield in the present study were higher with moringa rations, however, moringa contained higher tannins and polyphenols than berseem (see Table 2). The rate of out flow observed in this study with $\mathrm{R}_{5}$ could be considered as suitable rate of out flow for efficient microbial nitrogen synthesis.

Table (4): Overall mean of rumen parameters of sheep fed the experimental rations (means $\pm \mathrm{SE}$ ).

\begin{tabular}{lccccc}
\hline \multirow{2}{*}{ Item } & \multicolumn{4}{c}{ Experimental rations } \\
\cline { 2 - 6 } & $\mathrm{R}_{1}$ & $\mathrm{R}_{2}$ & $\mathrm{R}_{3}$ & $\mathrm{R}_{4}$ & $\mathrm{R}_{5}$ \\
\hline \multirow{2}{*}{$\mathrm{pH}$} & 6.44 & 6.42 & 6.36 & 6.31 & 6.28 \\
& $\pm 0.04^{\mathrm{a}}$ & $\pm 0.05^{\mathrm{a}}$ & $\pm 0.02^{\mathrm{ab}}$ & $\pm 0.07^{\mathrm{b}}$ & $\pm 0.05^{\mathrm{b}}$ \\
$\mathrm{NH}_{3}$-N concentration(mg/100ml) & 15.11 & 15.09 & 13.81 & 13.76 & 12.22 \\
& $\pm 0.09^{\mathrm{a}}$ & $\pm 0.06^{\mathrm{a}}$ & $\pm 0.17^{\mathrm{b}}$ & $\pm 0.11^{\mathrm{b}}$ & $\pm 0.19^{\mathrm{c}}$ \\
VFA's concentration (meq/100 ml) & 11.28 & 11.32 & 14.60 & 14.67 & 15.68 \\
Molar proportion \% & $\pm 0.32^{\mathrm{b}}$ & $\pm 0.14^{\mathrm{b}}$ & $\pm 0.24^{\mathrm{ab}}$ & $\pm 0.27^{\mathrm{ab}}$ & $\pm 0.18^{\mathrm{a}}$ \\
Acetic acid, \% & & & & \\
& 57.86 & 57.94 & 60.43 & 62.89 & 63.04 \\
Propionic acid, \% & $\pm 0.42^{\mathrm{b}}$ & $\pm 0.62^{\mathrm{b}}$ & $\pm 0.17^{\mathrm{ab}}$ & $\pm 0.76^{\mathrm{a}}$ & $\pm 0.33^{\mathrm{a}}$ \\
& 25.91 & 25.65 & 25.44 & 25.07 & 25.02 \\
Butyric acid, \% & \pm 0.52 & \pm 0.68 & \pm 0.610 & \pm 0.78 & \pm 0.71 \\
& 10.89 & 9.24 & 9.01 & 8.91 & 8.84 \\
Acetic : propionic ratio & \pm 0.16 & \pm 0.22 & \pm 0.17 & \pm 0.21 & \pm 0.12 \\
& 2.23 & 2.26 & 2.38 & 2.51 & 2.52 \\
Rumen volume (L) & $\pm 0.03^{\mathrm{b}}$ & $\pm 0.05^{\mathrm{b}}$ & $\pm 0.09^{\mathrm{ab}}$ & $\pm 0.06^{\mathrm{a}}$ & $\pm 0.01^{\mathrm{a}}$ \\
Rate of out flow (\% hr) & 3.05 & 3.24 & 3.36 & 3.44 & 3.68 \\
& $\pm 0.08^{\mathrm{d}}$ & $\pm 0.03^{\mathrm{c}}$ & $\pm 0.12^{\mathrm{b}}$ & $\pm 0.17^{\mathrm{b}}$ & $\pm 0.09^{\mathrm{a}}$ \\
Microbial nitrogen yield (g/d) & 6.20 & 6.14 & 6.06 & 5.93 & 5.64 \\
& $\pm 0.10^{\mathrm{a}}$ & $\pm 0.09^{\mathrm{a}}$ & $\pm 0.11^{\mathrm{b}}$ & $\pm 0.06^{\mathrm{b}}$ & $\pm 0.11^{\mathrm{c}}$ \\
\hline
\end{tabular}

$a, b, c$ and $d:$ means in the same row with different superscripts are significantly $(P<0.05)$ different.

$R_{l}=60 \% C F M+40 \%$ berseem (Trifolium alexandrinum).

$R_{2}=60 \% C F M+30 \%$ berseem (Trifolium alexandrinum) $+10 \%$ Moringa oleifera .

$R_{3}=60 \% C F M+20 \%$ berseem (Trifolium alexandrinum) $+20 \%$ Moringa oleifera .

$R_{4}=60 \% C F M+10 \%$ berseem (Trifolium alexandrinum) $+30 \%$ Moringa oleifera .

$R_{5}=60 \% C F M+40 \%$ Moringa oleifera.

\section{Degradation kinetics:}

Estimates of ruminal degradation contents ( $a, b$ and $c$ ) fitted with rates of DM and CP disappearance of tested roughages are presented in Table (5). The results illustrated that washing loss soluble degradable fraction\% "a", potentially degradable fraction\% "b", rate of degradation "c" and effective degradability "ED" of DM were lower $(\mathrm{P}<0.05)$ for berseem than moringa, meanwhile mixing berseem with moringa was associated with improving all degradable fractions than for berseem alone. The high degradable fractions of moringa DM could be regarded to its high contents of soluble ash and readily fermentable carbohydrates. Ndemanisho et al. (2007) reported that moringa leaves had higher values of ruminal DM degradation kinetics than leucaena. In the contrast, berseem had the highest $\mathrm{CP}(\mathrm{P}<0.05)$ degradation fractions of $\mathrm{a}$ and $\mathrm{b}$ and effective degradability "ED" either alone or in mixture in comparison to moringa. Highest $(\mathrm{P}<0.05)$ ruminal undegradable protein $(\mathrm{RUP})$ was recorded with $\mathrm{R}_{5}$, while $\mathrm{R}_{1}$ and $\mathrm{R}_{2}$ were recorded lowest values. Makkar and Becker (1996) reported that about $95 \%$ of moringa crude protein was found to be available either in the rumen or in the post rumen. The protein potentially digestible in the intestine (PDI) was $47 \%$ of the total crude protein of moringa. The PDI is available to the animal for 


\section{Khayyal et al.}

production purposes. They added that PDI values obtained for moringa leaves were much higher than those for various conventional protein supplements like seed meal. High crude protein contents and high PDI values of moringa leaves could suggest that these leaves are good source of protein supplement for high producing animals. Kleinschmit et al. (2007) cited that proteins that resist degradation in the rumen and pass to the lower tract for digestion" bypass" is necessary for maximizing production of ruminants and high producing dairy animals. They concluded that values of potential and effective degradability and rates of degradation of both $\mathrm{DM}$ and $\mathrm{CP}$ were affected by diet formulation and levels of fibrous carbohydrates rather than animal species.

\section{Average daily gain, feed intake, feed conversion and economic efficiency:}

Average daily gain, feed intake, feed conversion and economic efficiency are given in Table (6). Daily DM intake was nearly comparable among groups. Feed conversion was improved $(\mathrm{P}<0.05)$ with all moringa rations in comparison with $\mathrm{R}_{1}$ (40\% berseem). Aregheore (2002) found that feeding M. oleifera at 20 or $50 \%$ of the total daily forage intake to goats was resulted in better dietary protein utilization and feed conversion. Economic return and economic efficiency were higher with moringa than berseem. In this context, Adegun and Aye (2013) reported that the cost of produced milk was reduced when $M$. oleifera leaf meal replaced cotton seed meal in the rations of dairy cows, which in turn increase profits.

Table (5): Degradation kinetics of DM and CP of experimental forages (means $\pm \mathrm{SE}$ ).

\begin{tabular}{cccccc}
\hline \multirow{2}{*}{ Item } & \multicolumn{5}{c}{ Experimental rations } \\
\cline { 2 - 6 } & $\mathrm{R}_{1}$ & $\mathrm{R}_{2}$ & $\mathrm{R}_{3}$ & $\mathrm{R}_{4}$ & $\mathrm{R}_{5}$ \\
\cline { 2 - 6 } $\mathrm{a}$ & $28.11 \pm 0.17^{\mathrm{c}}$ & $28.65 \pm 0.52^{\mathrm{bc}}$ & $30.03 \pm 0.35^{\mathrm{b}}$ & $31.98 \pm 0.49^{\mathrm{a}}$ & $32.16 \pm 0.34^{\mathrm{a}}$ \\
$\mathrm{nyyyy} \mathrm{b}$ & $37.14 \pm 0.86^{\mathrm{c}}$ & $38.41 \pm 0.57^{\mathrm{c}}$ & $42.58 \pm 0.52^{\mathrm{b}}$ & $42.99 \pm 0.57^{\mathrm{b}}$ & $44.29 \pm 0.38^{\mathrm{a}}$ \\
$\mathrm{c}$ & $0.051 \pm 0.001^{\mathrm{d}}$ & $0.053 \pm 0.002^{\mathrm{c}}$ & $0.058 \pm 0.002^{\mathrm{b}}$ & $0.058 \pm 0.002^{\mathrm{c}}$ & $0.062 \pm 0.002^{\mathrm{a}}$ \\
$\mathrm{ED}$ & $51.49 \pm 0.17^{\mathrm{d}}$ & $53.18 \pm 0.22^{\mathrm{c}}$ & $58.09 \pm 0.30^{\mathrm{b}}$ & $60.31 \pm 0.37^{\mathrm{ab}}$ & $62.01 \pm 0.21^{\mathrm{a}}$ \\
\hline \multicolumn{5}{c}{$\mathrm{CP}$} & \\
$\mathrm{n}$ & $23.47 \pm 0.20^{\mathrm{a}}$ & $23.36 \pm 0.23^{\mathrm{a}}$ & $21.12 \pm 0.19^{\mathrm{b}}$ & $20.07 \pm 0.18^{\mathrm{c}}$ & $20.00 \pm 0.14^{\mathrm{c}}$ \\
$\mathrm{b}$ & $57.92 \pm 0.42^{\mathrm{a}}$ & $57.79 \pm 0.28^{\mathrm{a}}$ & $51.60 \pm 0.33^{\mathrm{b}}$ & $50.79 \pm 0.32^{\mathrm{b}}$ & $45.32 \pm 0.21^{\mathrm{c}}$ \\
$\mathrm{c}$ & $0.074 \pm 0.002^{\mathrm{a}}$ & $0.073 \pm 0.002^{\mathrm{a}}$ & $0.067 \pm 0.002^{\mathrm{b}}$ & $0.067 \pm 0.001^{\mathrm{b}}$ & $0.063 \pm 0.001^{\mathrm{c}}$ \\
$\mathrm{ED}$ & $64.68 \pm 0.12^{\mathrm{a}}$ & $64.32 \pm 0.17^{\mathrm{a}}$ & $56.76 \pm 0.11^{\mathrm{b}}$ & $55.15 \pm 0.32^{\mathrm{b}}$ & $50.70 \pm 0.22^{\mathrm{c}}$ \\
$\mathrm{RUP}$ & $35.32 \pm 0.44^{\mathrm{c}}$ & $35.68 \pm 0.34^{\mathrm{c}}$ & $43.24 \pm 0.39^{\mathrm{b}}$ & $44.85 \pm 0.30^{\mathrm{b}}$ & $49.30 \pm 0.21^{\mathrm{a}}$ \\
\hline
\end{tabular}

$a, b, c$ and $d:$ means in the same row with different superscripts are significantly $(P<0.05)$ different.

$a=$ soluble degradable fraction (\%). $b=$ potentially degradable fraction (\%).

$c=$ rate of degradability $(\% \mathrm{~h}-1)$. ED $=$ effective degradability $(\%)$.

$R U P=100-E D(\emptyset r s k o v$ and McDonald, 1979).

$R_{1}=60 \% C F M+40 \%$ berseem (Trifolium alexandrinum).

$R_{2}=60 \% C F M+30 \%$ berseem (Trifolium alexandrinum) $+10 \%$ Moringa oleifera .

$R_{3}=60 \% C F M+20 \%$ berseem (Trifolium alexandrinum) $+20 \%$ Moringa oleifera .

$R_{4}=60 \% C F M+10 \%$ berseem (Trifolium alexandrinum) $+30 \%$ Moringa oleifera .

$R_{5}=60 \% C F M+40 \%$ Moringa oleifera.

\section{Blood parameters:}

Table (7) illustrated that blood glucose was increased $(\mathrm{P}<0.05)$ with increasing moringa in rations compared with the control one. However, high blood glucose level with moringa feeding might support the assumption that, moringa forage could help in bypassing some soluble carbohydrates to be absorbed as glucose which helps in increasing the metabolizable energy intake. Annison et al. (2002) found a linear relationship between glucose entry rate and metabolizable energy intake. Total protein, albumin and globulin were higher $(\mathrm{P}<0.05)$ for male Barki sheep fed moringa rations $\left(\mathrm{R}_{3}, \mathrm{R}_{4}\right.$ and $\left.\mathrm{R}_{5}\right)$ than those fed berseem ration $\left(R_{1}\right)$, while no significant differ between $R_{1}$ and $R_{2}$. Moreover, blood cholesterol was decreased $(\mathrm{P}<0.05)$ with moringa rations, however the effect was more pronounced with $40 \%$ moringa ration. Urea was decreased with increasing moringa level in rations compared with $\mathrm{R}_{1}(40 \%$ berseem), while insignificantly differ $(\mathrm{P}>0.05)$ among rations of creatinine, aspartate (AST) and alanine (ALT) transaminases were concern. In other words, feeding moringa up to $40 \%$ of the whole daily ration did not badly affects liver or kidney functions. On the other hand, the significantly lower cholesterol level associated with feeding moringa may be related to the higher phytonutrients content of moringa than other common forages. Astuti et al. (2011) reported that saponins content in moringa had good effect on animal health as expressed in low serum cholesterol and normal essential fatty acids concentration. The 


\section{Khayyal et al.}

lower blood urea level associated with feeding moringa forage was expected from the higher dietary $\mathrm{N}$ utilization of rations containing moringa than that contained berseem (Table 3). Hoffmann et al. (2003) assumed that, the high utilization of moringa nitrogen could be regarded to its cationic protein and rumen microbes interaction that allow their availability in the small intestine in an intact form.

\section{CONCLUSION}

From the results of this study, it's fair to conclude that introducing Moringa oleifera green forage in partial or complete replacement of berseem (Trifolium alexandrinum) fodder is highly recommended to improve growth performance, health status and economic revenue of male Barki sheep. However, there is a need for more studies concerning with energy and protein utilization of fresh or dry moringa leaves in the feeding practices of sheep.

\section{REFERENCES}

Adegun, M.K. and P.A. Aye (2013). Growth performance and economic analysis of West African Dwarf rams fed Moringa oleifera and cotton seed cake as protein supplements to Panicum maximum. Am. J. Food\& Nutr., 3(2): 58-63.

Agriculture Economics and Statistics (2014). Ministry of Agriculture and Land Reclamation, Economics Affairs Sector, Bulletin of the Agriculture Statistics, Part (1), Winter crops, 2012/2013, February, 2014, Egypt.

Ahmad, V.U.; S. Perveen and S. Bano (1990). Saponins from the leaves of Guaiacum officinale. Phytochemistry, 29: 3287-3290.

Alexander, G.; B. Singh; A. Sahoo and T.K. Bhat (2008). In vitro screening of plant extracts to enhance the efficiency of utilization of energy and nitrogen in ruminant diets. Anim. Feed Sci. and Tech., 145: 229-244.

Al-Rabbat, M.F.; R.L. Baldwin and W.C. Weir (1971). In vitro nitrogen-tracer technique for some kinetic measures of rumen ammonia. J. Dairy Sci., 54: 150.

Annison, E.F.; D.B. Lindsay and J.V. Nolan (2002). Digestion and metabolism. In M. Freer \&H. Dove (Eds.), Sheep Nutrition. Cabi/Csiro,Wallingford New York, pp 95-118.

A.O.A.C. (2007). Official Method of Analysis (18th Ed.) Association of Official Analytical Chemists. Washington, D.C., U.S.A.

Aregheore, E.M. (2002). Intake and digestibility of Moringa oleifera and batiki grass mixtures by growing goats. Small Ruminant Research, 46: 23-28.

Armstrong, W.D. and C.W. Carr (1964). Physiological chemistry: Laboratory directions. 3rd Ed. U.S.A. Bunges Publishing Co. Minneapolis, Minnesota, pp. 75.

Asaolu, V.O. (2009). Integrated peri-urban systems: Horticulture and livestock in West African cities (Phase 3 of an IDRC-sponsored project executed by ITC, The Gambia); Final Technical Report. IDRC Research Results. IDL-BNC@IDRC.

Asaolu, V.O.; S.M. Odeyinka; O.O. Akinbamijo; O.J. Babayemi and E. Hoffmann (2009). Preliminary evaluation of Moringa oleifera and Oxytenanthera abyssinica (bamboo) leaves as feed supplements for ruminants. Bulletin for Animal Health and Production in Africa, 57: 349-360.

Asaolu, V.O.; A.K. Jarju; A. Joof; S.M. Odeyinka; J. Manne; D. Darboe and M. Jallow (2010). Moringa oleifera horticulture livestock integration approach to improving incomes and livelihoods of women farmers: the Gambian experience. IDRC Research Results. IDL- BNC@IDRC.

Astuti, D.A.; A.S. Baba and I.W. Wibawan (2011). Rumen fermentation, blood metabolites and performance of sheep fed tropical browse plants. Media Peternakan, pp. 201-206. 
Bakhashwain, A.A.; S.M. Sallam and A.M. Allam (2010). Nutritive value assessment of some Saudi Arabian foliages by gas production technique in vitro. JKAU: Met., Env. \& Arid Land Agric. Sci., 21(1): 65-80.

Becker, K. (1995). Studies on utilization of Moringa oleifera leaves as animal feed. Institute for Animal Production in the Tropics and Subtropics, vol. 480. University of Hohenheim, Stuttgart, pp. 15.

Ben Salem, H. and H. Makkar (2009). Defatted Moringa oleifera seed meal as a feed additive for sheep. Anim. Feed Sci. and Tech., 150: 27-33.

Bosch, C.H. (2004). Moringa oleifera Lam. In: Grubben, G. J. H.; Denton, O. A. (Eds). PROTA (Plant Resources of Tropical Africa / Ressources végétales de l'Afrique tropicale), Wageningen, Netherlands.

Chen, X.B.; E.R. Ørskov and F.D. Hovell (1991). The use of intragastric infusion in studies on excretion of purine derivatives as a measure of microbial protein supply in nutrition. National Institute of Animal Science Research Center, Foulum, 2: 67.

Das, T.K.; D. Banerjee; D. Chakraborty; M.C. Pakhira; B. Shrivastava and R.C. Kuhad (2012). Saponin: Role in Animal System. Vet. World, 5(4): 248-254.

Dei, H.K.; S.P. Rose and A.M. Mackenzie (2007). Shea nut (Vitellaria paradoxa) meal as a feed ingredient for poultry. In World's Poultry Science Journal, 63(4): 611-624.

Doumas, B.T.; W.A. Waston and H.G. Biggs (1971). Albumin standards and the measurements of serum albumin with bromocresol green. Clin. Chem. Acta., 31: 87-96.

Duncan, D.B. (1955). Multiple range and multiple F- test. Biometric, 11: 1-42.

El-Shazly, K.; E.I. Ahmed; M.A. Naga and B.E. Borhami (1976). A calorimetric technique using chromium-ethylen diamins tetracetate for measuring rumen volume. J.Agric.Sci.Camb., 87: 369-373.

FAO (2014). Moringa. Traditional Crop of the Month. FAO. http://www.fao.org/traditionalcrops/moringa/en.

Faulkner, W.R. and J.W. King (1976). Fundamentals of Clinical Chemistry, 2nd ed. (NW Tietz, Ed.), Saunders, Philadelphia, pp. 994-998.

Ferreira P.M.; D.F. Farias; J.T. Oliveira and A. Carvalho (2008). Moringa oleifera: Bioactive compunds and nutritional potential. Revista de Nutrição, Campinas, 21(4): 431-437.

Foidl, N.; H.P. Makkar and K. Becker (2001). The potential of Moringa oleifera for agricultural and industrial uses. What development potential for moringa products? October $20^{\text {th }}$ - November $2^{\text {nd }} 2001$. Dar Es Salaam.

Fujihara, A.; S. Fajemilehin and A. Omojola (2005). The egg quality characteristics of layers fed varying dietary inclusions of Siam weed (Chromolaena odorata) leaf meal (SWLM). Int. J. Poult. Sci., 4:752757.

Gidamis, A.; J. Panga; S. Sarwatt; B. Chove and N. Shayo (2003). Nutrients and antinutrients contents in raw and cooked leaves and mature pods of Moringa oleifera Lam. Ecology and Food Nutrition, 42: 1123.

Gupta, K.; G.K. Barat; D.S. Wagle and H.K.L. Chawla (1989). Nutrient contents and antinutritional factors in conventional and nonconventional leafy vegetables. Food Chem., 31: 105-116.

Henry, J.B. and S.D. Todd (1974). Clinical Diagnosis and Measurement by Laboratory Methods., 16th Ed., W.B. Saunders and Co., Phliadephia., PA. P 260.

Hoffmann, E.M.; S. Muetzel and K. Becker (2003). Effect of Moringa oleifera seed extract on rumen fermentation in vitro. Arch. Anim. Nutr., 57: 65-81.

Kaijage, J.T.; S.V. Sarwatt and S.K. Mutayoba (2003). Moringa oleifera leaf meal can improve quality characteristics and consumer preference of marketable eggs. Numerical Proceedings Papers.

Kamel, H.E.M.; J. Sekine; T. Suga and Z. Morita (1995). The effect of frozen-rethawing technique on detaching firmly associated bacteria from in situ hay residues. Can. J. Anim. Sci., 75: 481-483.

Khalel, M.S.; A.M. Shwerab; A.A. Hassan; M.H. Yacout; A.Y. El-Badawi and Mona S. Zaki (2014). Nutritional evaluation of Moringa oleifera fodder in comparison with Trifolium alexandrinum 


\section{Khayyal et al.}

(berseem) and impact of feeding on lactation performance of cows. Life Science Journal, 11(10): 1040-1054.

Kimoro, B.N. (2002). Potential of selected Multipurpose trees as feed for growing goats on maize stover basal diet. M.Sc. Thesis, Sokoine University of Agriculture, Morogoro, Tanzania.

Kleinschmit, D.H.; J.L. Anderson; D.J. Schingoethe; K.F. Kalscheur and A.R. Hippen (2007). Ruminal and intestinal degradability of distillers grains plus soluble varies by source. J. Dairy Sci., 90: 29092918.

Makkar, H.P.S. (2003). Quantification of tannins in tree and shrub foliage. In: Makkar, H.P.S. (Ed.), A Laboratory Manual Kluwer Academic Publishers. FAO/IAEA, Vienna, Austria, pp. 102.

Makkar, H.P.S. and K. Becker (1993). Behaviour of tannic acid from various commercial sources towards some chemical and protein precipitation assays. J. Sci. Food Agric., 62: 295-299.

Makkar, H.P. and K. Becker (1996). Nutritional value and antinutritional components of whole and ethanol extracted Moringa oleifera leaves. Anim. Feed Sci. Tech., 63: 211-228.

Makkar, H.P.S. and K. Becker (1997). Nutrients and anti-quality factors in different morphological parts of the Moringa oleifera tree. J. Agric. Sci. Camb., 128: 311- 332.

Malik, M.Y.; A.S. Abhtar and W.H. Shah (1967). Chemical composition of indigenous fodder leaves (M. pterygosperma). Pak. J. Sci., 19:171-174.

Manh, L.; N. Nguyen and T. Ngoi (2005). Introduction and evaluation of Moringa oleifera for biomass production and feed for goats in the Mekong delta. Livestock Research for Rural Development, 17: 9.

McDonald, I. (1981). A revised model for the estimation of protein degradability in the rumen. J. Agric. Sci. Camb., 96: 251.

Mehrez, A.Z. and E.R. Ørskov (1977). A study of the artificial fibre bag technique for determining the digestibility of feeds in the rumen. J. Agri. Sci., Camb., 88: 645- 650.

Mendieta-Araica, B.; R. Spörndly; N. Reyes-Sánchez and E. Spörndly (2011). Moringa (Moringa oleifera) leaf meal as a source of protein in locally produced concentrates for dairy cows fed low protein diets in tropical areas. Livestock Science, 137: 10-17.

Mendieta-Araica, B.; R. Spörndly; N. Reyes-Sánchez; F. Salmerón-Miranda and M. Halling (2013). Biomass production and chemical composition of Moringa oleifera under different planting densities and levels of nitrogen fertilization, Agroforestry Systems, 87(1): 81-92.

Moyo, B.; P. Masika; A. Hugo and V. Muchenje (2011). Nutritional characterization of Moringa (Moringa oleifera Lam.) leaves Afr. J. Biotechnol., 60: 12925-12933.

Ndemanisho, E.E.; B.N. Kimoro; E.J. Mtengeti and V.R. Muhikambele (2007). In vivo digestibility and performance of growing goats fed maize stover supplemented with browse leaf meals and cotton seed cake based concentrates. LRRD 19 (8). www.lrrd.org/lrrd19/ 8 /ndem19105.htm.

Newton, K.A.; R.N. Bennett; R.B. Curto; E.A. Rosa; V.L. Turc; A. Giuffrida; A.L. Curto; F. Crea and G.M. Timpo (2010). Profiling selected phytochemicals and nutrients in different tissues of the multipurpose tree Moringa oleifera L., grown in Ghana. Food Chem., 122: 1047-1064.

Nouman, W.; S.M. Basra; M.T. Siddiqui; A. Yasmeen; T. Gull and M.A. Alcayde (2013). Potential of Moringa oleifera L. as livestock fodder crop: a review. Turk. J. Agric., doi: 10.3906/tar-1211-66.

NRC (1994). Nutrient Requirements of Small Ruminants. National Academy Press, Washington, DC.

Ogbe, A.O. and P. John Affiku (2011). Proximate study, mineral and anti-nutrient composition of Moringa oleifera leaves harvested from Lafia, Nigeria: potential benefits in poultry nutrition and health. Journal of Microbiology. Biotechnology and Food Services, 2011/12; 1(3): 296-308.

Ojiako, E.N. (2014). Phytochemical Analysis and Antimicrobial Screening of Moringa oleifera Leaves. Extract the International Journal of Engineering and Science (IJES), Volume (3), Issue 3, Pages 3235, ISSN (e): 2319 - 1813 ISSN (p): 2319-1805.

Oliveira, J.T.; S.B. Silveira; I.M. Vasconcelos; B.S. Cavada and R.A. Moreira (1999). Compositional and nutritional attributes of seeds from the multipurpose tree Moringa oleifera L. J. Sci. Food Agric., 79: 815-820. 
Ørskov, E.R. and I. McDonald (1979). The estimation of protein degradability in the rumen from incubation measurements weighed according to rate of passage. J. Agric. Sci. Camb., 92: 499.

Orwa, C.; A. Mutua; R. Kindt; R. Jamnadass and S. Anthony (2009). Agroforestree Database: a tree reference and selection guide version 4.0. World Agroforestry Centre, Kenya.

Poppi, D.P. and S.R. McLennan (1995). Protein and energy utilization by ruminants at pasture. J. Anim. Sci., 73: 278-290.

Radovich, T. (2009). In: Elevitch, C.R. (Ed.) Specialty Crops for Pacific Island Agroforestry. Permanent Agriculture Resources (PAR), Holualoa, Hawai'i.

Reitman, S. and S. Frankel (1957). A calorimetric method for the determination of serum glutamic oxaloacetic and glutamic pyruvic transaminases. Amer. J.Clinc. Path., 28: 56.

Reyes-Sánchez, N.; S. Ledin and I. Ledin (2006a). Biomass production and chemical composition of Moringa oleifera under different management regimes in Nicaragua. Agroforestry Systems, 66: 231242.

Reyes-Sánchez, N.; E. Spörndly and I. Ledin (2006b). Effect of feeding different levels of foliage of Moringa oleifera to creole dairy cows on intake, digestibility, milk production and composition. Livestock Science, 1001: 24-31.

Roeschlau, P.; E. Bernt and W.J. Gruber (1974). Estimation of cholesterol .Clin. Chem. Clin. Biochem., 12: 403.

Sarwatt, S.V.; S.S. Kapange and A.M.V. Kakengi (2002). The effects on intake, digestibility and growth of goats when sunflower seed cake is replaced with Moringa oleifera leaves in supplements fed with Chloris gayana hay. Agroforestry systems, 56: 241-247.

SAS (2000). SAS users guide: Statistics, SAS Inst., Inc., Cary N.C., USA.

Sliwinski, B.J.; C.R. Soliva; A. Machmüller and M. Kreuzer (2002). Efficacy of plant extracts rich in secondary constituents to modify rumen fermentation. Anim. Feed Sci. Tech., 101: 101-114.

Soliva, C.R.; M. Kreuzera; N. Foidlb; G. Foidlb; A. Machmüllera and H.D. Hessa (2005). Feeding value of whole and extracted Moringa oleifera leaves for ruminants and their effects on ruminal fermentation in vitro. Anim.Feed Sci. and Tech., 118: 47-62.

Sutherland, J.P.; G.K. Folkard and W.D. Grant (1990). Natural coagulants for appropriate water treatment: a novel approach, Waterlines, April (4): 30-32.

Thurber, M.D. and J.W. Fahey (2009). Adoption of Moringa oleifera to Combat Under-Nutrition Viewed Through the Lens of the "Diffusion of Innovations" Theory. Ecol Food Nutr., 48(3): 212-225.

Trinder, P. (1969). Ann. Clin. Biochem. Biochem., 6, 24 March 26th (9)VI.I.

Van Soest, P.J.; J.B. Robertson and B.A. Lewis (1991). Methods for dietary fibre, neutral detergent fibre and non-starch polysaccharides in relation to animal nutrition. J. Dairy Sci., 74: 3583-3597.

Vitti, D.M.; E.F. Nozella; A.L. Abdalla; I.C. Bueno; J.C. Silva Filho; C. Costa; M.S. Bueno; C. Longo; M.E. Vieira; S.L. Cabral Filho; P.B. Godoy and I. Mueller-Harvey (2005). The effect of drying and urea treatment on nutritional and anti-nutritional components of browses collected during wet and dry seasons. Anim. Feed Sci. Tech., 122: 123-133.

Warner, A.C.I. (1964). Production of volatile fatty acids in the rumen, methods of measurement. Nutr. Abst. and Rev., 34: 339.

Yang, C.M. and G.A. Varga (1989). Effect of three concentrate feeding frequencies on rumen protozoa, rumen digesta kinetics, and milk yield in dairy cows. J. Dairy Sci., 72: 950-957. 


\title{
Khayyal et al.
}

\section{أثر الإحلال الكلي أو الجزئي للبرسيم من المورينجا على الأداء الإنتاجى للأغنام.}

\author{
أماني أمين خيال، عمرو محمد حلمى شويرب، محمد سمير محمود خليل، أيمن عبد المحسن حسن و محمد حلمي ياقوت \\ قسم بحوث إستخدم المخلفات، معهب بحوث الإنتاج الحيوانى، مركز البحوث الزراعية، الدقى، الجبيزة، مصر
}

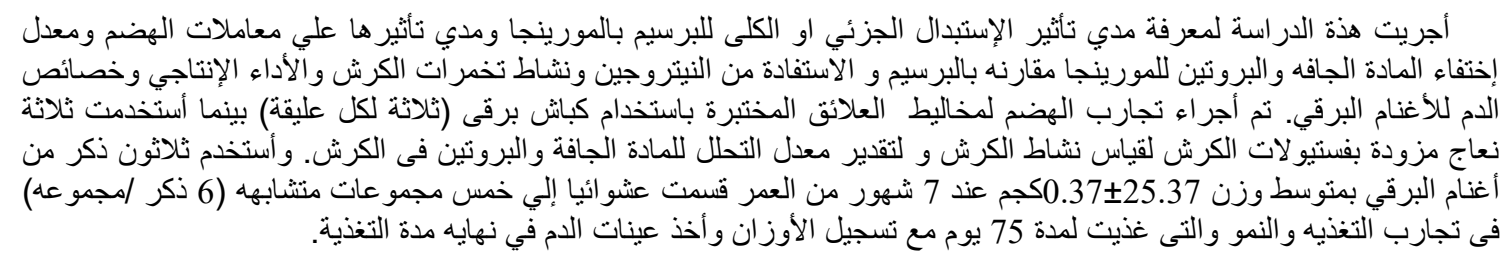

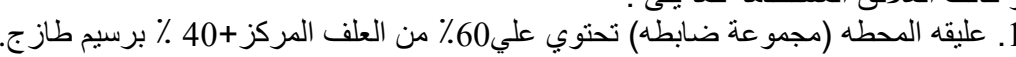

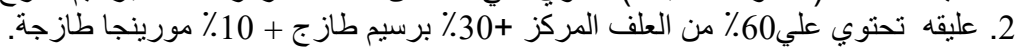

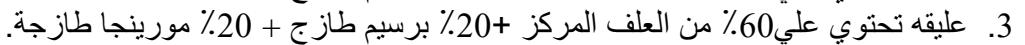

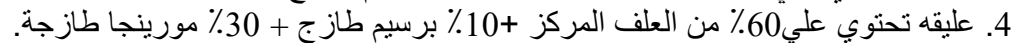

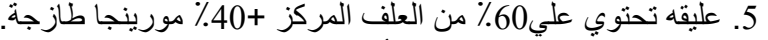

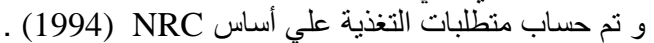

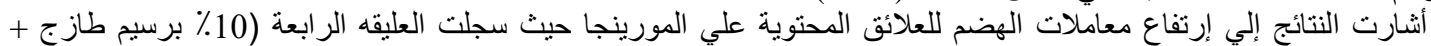

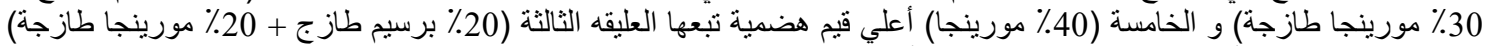

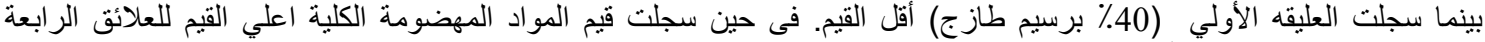

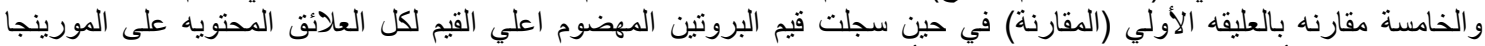

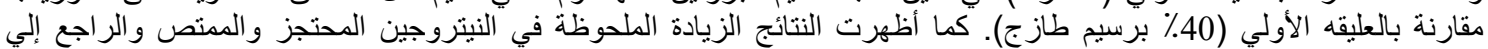

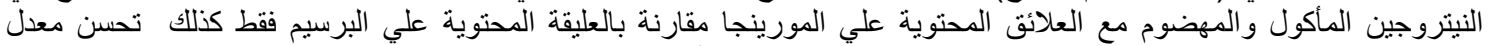

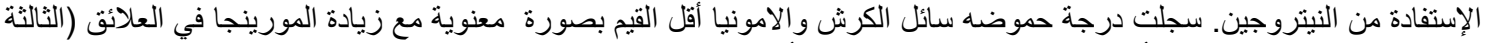

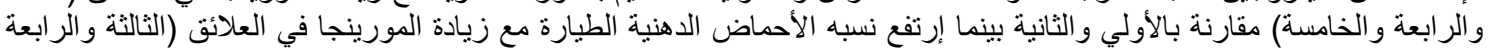

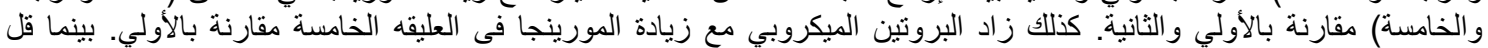

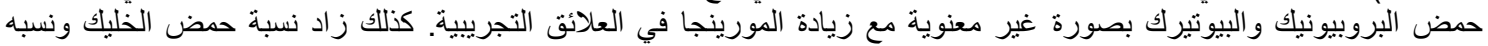

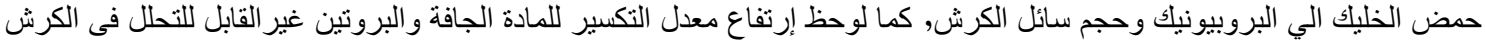

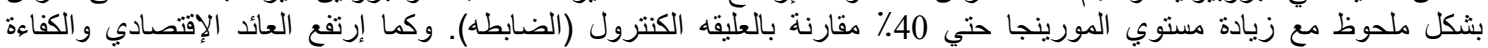

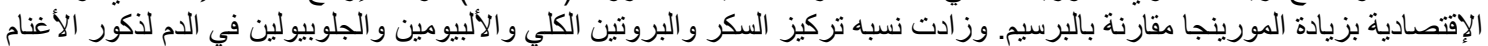

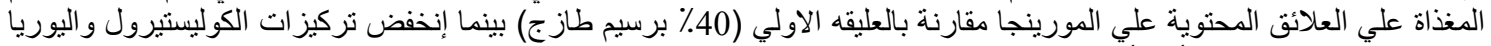

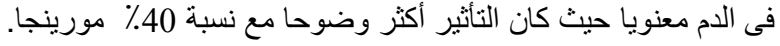

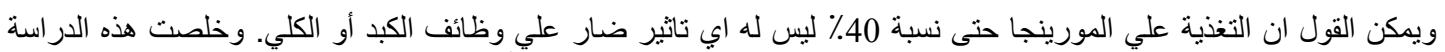

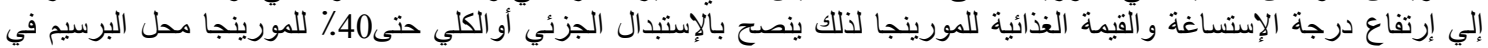
علائق تغذية الأغنام لما لذلك تأثير على تحسن الأداء والإستفاده الأقتصاديه. 